\title{
The Isopathic Phenomenon of Sagher Preliminary Report on Leprosy Patients in the Philippines
}

PERPETUA D. REYES-JAVIER, M.D., MEDICAL SPECIALIST

Division of Sanitaria, Bureau of Discase Control, Manila

The isopathic phenomenon first described by SAGHer and his associates in $195^{2}$ is the term applicd to a 'specific altered tissue reactivity', as the result of which the intradermal injection of certain substances produces a histological response characteristic of the disease itself. 'This phenomenon is distinct from the isomorphic phenomenon of кö̈BNER, in which identical skin lesions are produced on unaffected skin by any kind of injury. This phenomenon is scen in such discases as psoriasis, lichen nitidus, verruca plana, and infectious eczematoid dermatitis ${ }^{1}$.

SAGHER, KOCSARD, and LIBAN ${ }^{2}$ observed the isopathic phenomenon in biopsy sections of nodules produced by the injection of tuberculin in patients with inactive lepromatous leprosy. They subsequently studied the effect of other proteins, specific and non-specific, e.g. leishmania, living tubercle bacilli, milk and peptone solution ${ }^{3},{ }^{4},{ }^{5},{ }^{6},{ }^{7}$ and $\left.{ }^{8}\right)$. Their observations were confirmed by RICHTER ${ }^{9}$, who inoculated leprosy patients with tuberculin, milk and india-ink, and by WAALER ${ }^{10}$ who used intradermal injections of old tuberculin.

In view of the possible importance of the isopathic phenomenon, certain studies have been made on patients suffering from different kinds of leprosy, on patients with various dermatoses and on healthy contact of leprosy patients.

\section{PATIENTS AND METHODS}

A total of sixty-seven leprosy patients from the Leprosy Rescarch and Training Centre, Department of Health, Manila, and from the Central Luzon Sanitarium, Novaliches, Rizal, were included in this study. They were grouped as follows: indeterminate, 4 ; typical tuberculoid, 6 ; tuberculoid in reaction, I 8; reactional tuberculoid, 3 ; inactive tuberculoid, 2 ; maculo-anaesthetic, 5; borderline, 3 ; lepromatous, 15 ; primary polyneuritic, II. For controls, patients with diverse dermatoses and three contacts of leprosy patients were chosen. The classification of each type was based on clinical characteristics and bacteriological examination from different sites. Clinical and pathological findings were correlated by the author.

INDETER MINATE

Clinical - one to few ill-defined smooth hypopigmented macules some of which were partially or totally anaesthetic. There was no history of previous erythema on the sites involved.

Acid-fast smears - negative.

Histopathology - perivascular lymphocytic infiltrate. 
TYPICAI. TUBERCUI.OII)

Clinical - one to several circinate anaesthetic patches of various sizes with narrow, red, flat or slightly elevated borders.

Acid-fast smears - negative.

Histopathology-evidence of typical tubercles.

TUBERCULOII IN REACTION

Clinical - Few to several anaesthetic patches of various sizes, some of which showed circinate pattern, others with varying degrees of infiltration of the lesion. Some patients had nerves slightly or moderately enlarged, with or without slight to moderate tenderness. Acid-fast smears - negative.

Histopathology - 16 of the 18 patients showed typical tuberculoid reaction; one had perivascular lymphocytic infiltrate; no biopsy was performed on the remaining patients.

\section{REACTIONAI, TUBERCUIOOII)}

Clinical - Markedly infiltrated large patches (which had been originally typically tuberculoid), and irregularly disseminated red papulo-nodules.

Acid-fast smears ; + to ++

Histopathological - All 3 cases showed granulomatous foci composed chiefly of epithelioid cells and lymphocytes, although the tuberculoid pattern could be seen with difficulty in some biopsy sections. Intercellular and intracellular oedema was evident.

INACTIVE TUBERCULOID

Clinical-Hypopigmented anaesthetic patches which were previously red and elevated; with enlarged non-tender nerves supplying the involved site.

Acid-fast smears - negative.
Histopathological - perivascular lymphocytic infiltrate.

MACULO-ANAESTIETIC

Clinical - Multiple hypopigmented large smooth anaesthetic macules with atrophy and/or contractures of the muscles of one or more limbs.

Acid-fast smears - negative.

Histopathological - perivascular lymphocytic infiltrate in one patient; no biopsy was performed on two patients.

BORIDERIII NE

Clinical - Generalized coppery-red papulonodules, with borders not well-defined. One patient developed erythema nodosum during treatment.

Acid-fast smears $;++$ to +++

Histopathological - non-specific granulomatous infiltrate.

\section{I.EPROMATOUS}

Clinical - Generalized infiltrated yellowishred patches and papulo-nodules; some, with leonine face, madarosis and enlarged earlobes.

Acid-fast smears - markedly positive.

Histopathological - not done.

PRIMARY POLYNEURITIC

Clinical - no skin lesions either at the time of examination or before. Some showed either atrophy or contracture or both while others had anaesthetic patches.

Acid-fast smears - negative.

Histopathological - seven patients showed no tissue reaction in sections from anaesthetic areas; in four patients biopsy was not performed.

The materials used for intradermal injections were: triple-distilled water; peptone solution ( $\mathrm{I}-5$ per cent), 'Bear Brand' milk (o. I per cent); and lepromin (prepared by Mabalay of Eversley Childs Sanitarium, Cebu, Philippines); about o. I ml. of the test solution was injected intradermally on the antero-medial aspect of the thigh. For comparative studies, some patients received several tests. When multiple tests were done on the same patient, the antigens, including lepromin, were either given on both thighs at symmetrical sites, or the skin tests were done $\mathrm{I}-2 \mathrm{~cm}$. apart on one thigh. The test sites were marked by silver nitrate solution (I o per cent) drawn $2-3 \mathrm{~mm}$. around the point of injection. All the skin tests including lepromin were read after three to four weeks and recorded according to the following notation: doubtful $(\mathrm{I}-3 \mathrm{~mm}) ;.+(3-5 \mathrm{~mm}) ;$. $\left(5^{-10} \mathrm{~mm}.\right) ;+++$ (more than Io mm.) or less if there was ulceration. To study the effect of trauma, a dry 24-gauge needle was used. 


\section{HISTOLOGICAL EVALUATION OF THE SKIN TEST SITES}

In the indeterminate and maculo-anaesthetic forms of leprosy, the tissue response at the inoculation sites was that of non-specific banal inflammatory infiltrate, chiefly perivascular. perineural, or peri-adnexal. In some instances, a few cpithelioid cells were found at the centre of the lymphocytic foci. The tubcrculoid tissue response was characterized by granulomatous foci, discrete or coalescent, predominantly of epithelioid cells and lymphocytes in different proportions, and in some cases of one or more giant cells of Langhan's typc. The common tissue response consisted of a tubercle composed of centrally grouped cpithelioid cells surrounded by a zone of lymphocytes. In inactive lesions the tuberculoid element had disappeared, and only perivascular lymphocytic infiltrate was found.

SUMMARY OF OBSERVATIONS

TISSUE RESPONSE IN SITES INOCUI.ATED WITH I)ISTILLEI) WATER AND LEPROMIN

SIMUITTANEOUSLY

\section{Tuberculoid leprosy - (20 patients -} various types:

Lepromin: tuberculoid response (19 patients); non-specific granuloma (I patient).

Iistilled water: tuberculoid response (15 patients): non-specific granulomatous infiltrate or perivascular banal inflammatory infiltrate (4 patients); no response (I patient). 2. Primary neural leprosy (I I patients): Lepromin: tuberculoid response (6 patients): non-specific perivascular round-cell infiltrate ( $\mathrm{I}$ patient); 4 patients were not given lepromin.

Distilled water: tuberculoid response (5 patients) : perivascular lymphocytic infiltrate (6 patients).

3. Indeterminate leprosy (3 patients) : Lepromin: tuberculoid response (3 patients). Distilled water: tuberculoid response (I patient); no response ( 2 patients).

N.B.-All these patients subsequently developed tuberculoid features clinically.

\section{Maculo-Anaesthetic leprosy}

(2 patients):

Lepromin: tuberculoid response (2 patients). Distilled water: tuberculoid response (I patient); no response (I patient).

5. Borderline leprosy (3 patients) :

Lepromin : non-specific granuloma (I patient); no reaction (2 patients).

Distilled water: perivascular lymphocytic infiltrate ( 2 patients); non-specific granuloma (I patient).

6. Lepromatous leprosy (5 patients) :

Distilled water: lepromatous response (4 patients): perivascular lymphocytic infiltrate (I patient).

Lepromin test: not done.
TISSUE RESPONSE IN SITES INOCULATED WITI PEPTONE SOLUTION ANI) LEPROMIN SIMULTANEOUSLY:

I. Tuberculoid leprosy ( 2 patients, various types):

Lepromin: Tuberculoid response (9 patients); perivascular lymphocytic and granulomatous response ( 2 patients); I patient was not given lepromin.

Peptone: tuberculoid response (5 patients) banal inflammatory infiltrate (2 patients); no tissue response (5 patients).

2. Primary neural leprosy (6 patients):

Lepromin: tuberculoid response (2 patients); 4 patients were not given lepromin.

Peptone: tuberculoid response (4 patients); non-specific banal inflammatory infiltrate (2 patients).

3. Indeterminate leprosy (I patient) : Lepromin: tuberculoid response.

Peptone: perivascular lymphocytic infiltrate. 4. Borderline leprosy (3 patients) :

Lepromin: non-specific granulomatous response (I patient); no response ( 2 patients). 5. Lepromatous leprosy (5 patients): Peptone: lepromatous response (3 patients); no response (2 patients).

Lepromin: not given.

TISSUE RESPONSE IN SITES INOCULATED WITH MILK AND LEPROMIN SIMULTANEOUSLY:

I. Tuberculoid leprosy (3 patients):

Lepromin: tuberculoid response (2 patients); perivascular lymphocytic infiltrate (I patient).

Milk: tuberculoid response (2 patients); perivascular lymphocytic infiltrate (I patient).

2. Primary neural leprosy (4 patients) : Lepromin: tuberculoid response (2 patients); non-specific banal inflammatory infiltrate 


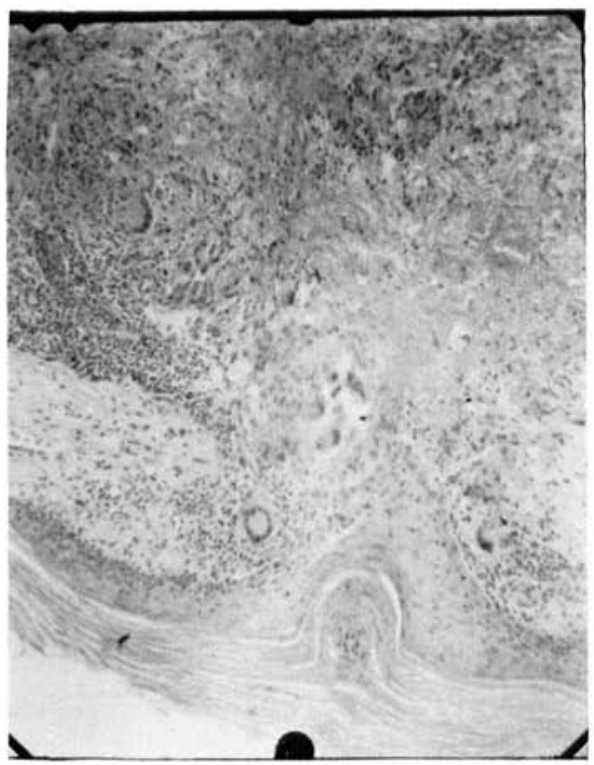

FIs. I. Site injected with distilled water in a patient with tuberculoid leprosy, showing the typical tuberculoid features of the tissue reaction. $2600 \times$

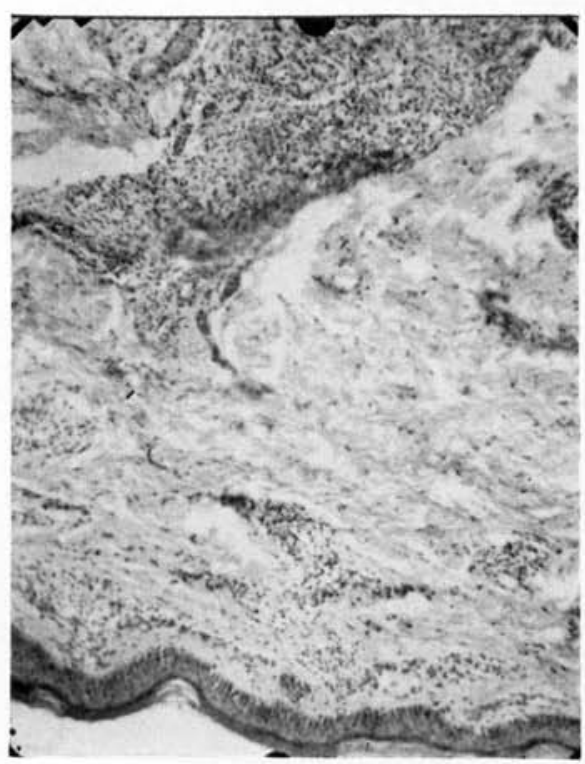

FIG. 3. Site injected with distilled water in a patient with lepromatous leprosy showing focalized lepromatous tissue in the superficial dermis and massive granuloma in the deeper layers.

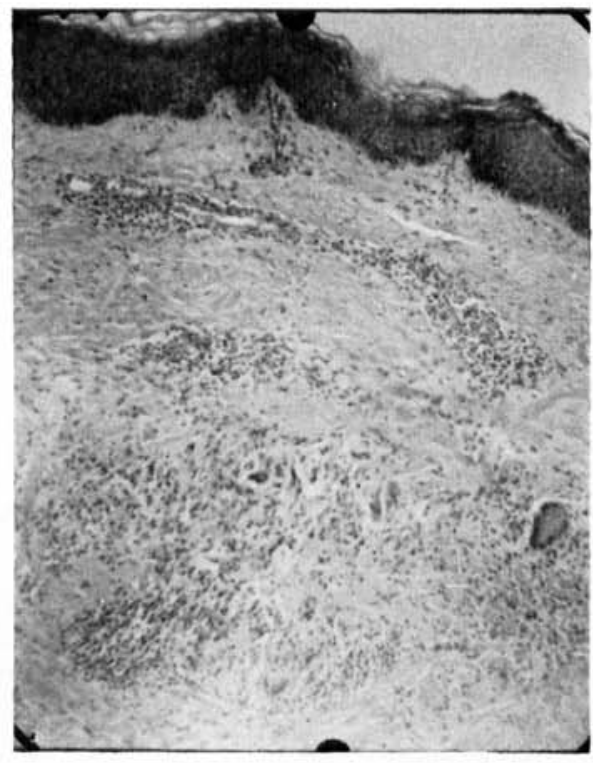

Fic. 2. Site injected with peptone solution in a patient with primary neural type of leprosy showing the tuberculoid histology of tissue reaction. $2600 \times$

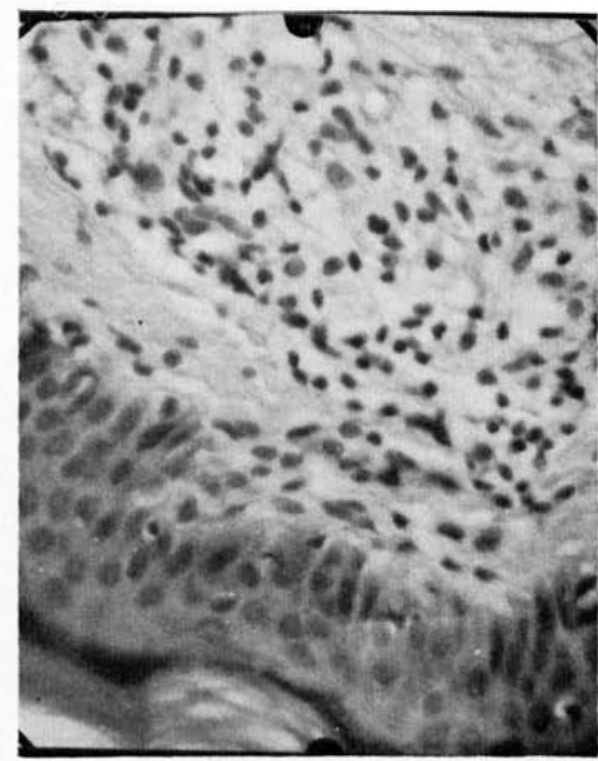

FIG. 4. High power magnification of a part of the skin in Fig. 3 showing the foam cells. 12, $35^{\circ} \times$ 
( 1 patient); I patient was not given lepromin.

Milk: tuberculoid response (I pationt): perivascular lymphocytic infiltrate (3 patients).

3. Indeterminate leprosy (3 patients):

Lepromin: tuberculoid response (3 patients). Milk: perivascular lymphocytic infiltrate: (3 patients).

4. Maculo-anaesthetic leprosy (I patienl) : Lepromin: luberculoid response.

Milk: unberculoid response.

5. Lepromatous leprosy (I patient):

Leforomin: no tissue response.

Milk: perivascular lymphocytic infiltrate.

TISSIIE RESHONSI T() TRAUMA:

Tuberculoid leprosy (3 patients) :

Lepromin : tuberculoidresponse (all 3 patients).

Response to trauma: no response (all 3 patients).

TISSUE RESPONSE TO I.EPROMATOUS PATIENTS TO I.EPROMIN ALONE: (5 patients):

Lepromatous response (4 patients):

Tuberculoid response: (1 paticnt).
TISSEF RESPONSE IN PATIENTS WTTI VARIOUS 1) HRMATOSLS

Pationts sulfering from the following dermatological conditions were selected for intradermal injections: pityriasis mulora pilaris, granuloma annulare, discoicl lupus erythematosus, lupus verrusosus cutis and postencephalitic claw-hand. No recognizable tissue reactions were obtained at sites injected with peptone, distilled water, milk and lepromin, with the sole exception of the tuberculoid response at the site of lepromin injection in the patient with gramuloma anmulare reported by the author (11) whose lesion on the right wrist was anaesthetic for a period of six months.

TISSUT: RESPONSF IN MEATITHY CONTACTS OF I.EPROSY PATITNTS

()f the three contacts of patients with leprosy who were tested by intradermal injections of water, milk and lepromin, one gave a tuberculoid response at the sites of injection of water and lepromin; another showed a similar response at the site of the lepromin injection alone, while the third patient showed tuberculoid features at the sites of the milk and lepromin injections.

I. Histological reactions of typical tuberculoid granulomatous aspect were seen in majority of patients with tuberculoid leprosy, irrespective of the precise kind of tuberculoid disease they were suffering from and irrespective also of the nature of the substance injected.

2. In primary neural leprosy, most of the test sites that were strongly positive showed tuberculoid histology, and most of the test sites that were negative showed perivascular lymphocytic infiltrate.

3. Patients with indeterminate and maculo-anaesthetic leprosy showed tuberculoid response at the test sites, specially noticeable at the sites where distilled water had been injected.

4. In borderline and lepromatous leprosy, non-specific granulomatous infiltrate and lepromatous changes were observed respectively at the test sites.

5. The fact that trauma by itself failed to elicit a typical tuberculoid response suggest that some substances must be introduced intradermally in order to excite the corresponding tissue reaction.

6. Patients with diverse dermatoses failed to give recognizable tissue response at the test sites.

7. Some contacts of patients with leprosy showed a tuberculoid response at the sites where water, milk or lepromin had been injected.

8. Distilled water injections showed the most typical tissue reaction in this experiment. 
9. Injection of lepromin cvoked a typical example of the phenomenon of SAGHER.

Io. No definite conclusion can be made on the advantage or disadvantage of the injection of test substances on the same or both thighs, duc to variability of results.

In intradermal injections of different test substances on opposite thighs at symmetrical points, 72 per cent gave similar tissue reactions, while the remaining 28 per cent gave diverse pathological findings. In patients where multiple tests were done on the same thigh, only i 7 per cent of the cases gave similar tissue response at the various test sites.

\section{CONCLUSIONS}

Further studies of SAGHER's phenomenon should be undertaken in view of its possible bearing on immunology in leprosy. In particular, latent leprosy with no cutaneous lesions might be detected by this means, for example among contacts and spouses.

Again, the type of leprosy might be indicated on histological grounds in patients whose clinical lesions though due to leprosy are typical in nature and insufficient for purposes of classification.

\section{A CKNOWLEDGEMENT}

My thanks are expressed to DR. S. G. BROWNE, F.R.C.P., and to DR. C. LARA for their generous help and suggestions in the preparation of this paper; to DR. IGNACIO, MR. MAGTOTO and MR. JOVELLANOS for their help in the illustration; to MR. BELEN and his staff for their co-operation and technical assistance; and to the Department of Health for permission to publish.

\section{References}

I. Andrews, c. G., Diseases of the Skin, Philadelphia and London. w. B. SAunders Co., I955, pp. I 76-205.

2. SAGHeR, F., KOCSARI), E., and I.IBAN, E. Internat. J. Leprosy I955, 20, 34I

3. Sagher, F., Kocsard, E., and liban, E. J. invest. Derm. 1952, 19, 499-508.

4. SAgher, F., Kocsard, E., and liban, E. J. invest. Derm. I 953, 20, 343-353.

5. KOCSARD, E., and SAgher, F. J. invest. Derm. I 953, 21, 69-70.

6. sagher, F., liban, E., zuckerman, A., and kocSard, E. Internat. J. Leprosy i $953,21,459$.

7. Sagher, f., Liban, E., and kocsard, E. A.M.A. Arch. Derm. Syph. i954, 7o, 631-637.

8. liban, E., zuckerman, A., and sagher, F. A.M.A. Arch. Derm. Syph. i 955, 7J, 441-450.

9. WADE, H. W. Internat. J. Leprosy $1957,25,246-265$.

IO. WAALER, E. Internat. J. Leprosy I 957, 25, 207-2 I I.

i i. Reyes, J., Rodriguez, J. J. Phil. med. Assoc. I 959, 35, 242-248. 